\title{
MODEL OF IMPROVING PERFORMANCE MANAGEMENT PRACTICE BASED EMPLOYEE PERFORMANCE MEDIATED BY EMPLOYEE WORK ATTITUDE
}

\author{
Mena Qomari ${ }^{1 *}$, Ibnu Khajar ${ }^{2 *}$
}

\footnotetext{
* Affiliation:

1,2 Magister Management Program, Islam Sultan Agung Islamic University
}

\begin{abstract}
:
The present study intended to test a model in which performance management practice and Islamic values predict work attitude and employee performance. A total of 100 respondents completed questionnaires on performance management practice, employee work attitude, Islamic values, and employee performance. The results from structural equation modeling based smartPLS 3.0 confirmed that 1) performance management practice is positively related to work attitude and employee performance; 2) work attitude is positively related to employee performance; and 3) Islamic values moderates the relationships between work attitude and employee performance.
\end{abstract} Keywords : Performance management practice, Work attitude, Islamic values, Employee performance

\section{INTRODUCTION}

Based on current global conditions, organizations are really faced with competition and challenges that are increasingly occured in all areas, whether in finance, technology, infrastructure, equipment, and human resources. Human resources are seen as an important factor in the organization because they are actively engaged in running the organization. Therefore, improving the quality of human resources becomes a major requirement in encouraging the improvement of performance in order to achieve their goals.

Hospital organization which is full of human resources from various educational background, has big enough challenge i.e. always trying to improve health service to society. Health service standards established by the Government require hospital management to produce high performance, in order to attract the hearts of people in need of health services.

It is how importance human resource issues, then the leader of the organization should put the improvement of HR performance on the main priority. Therefore, Performance Management, especially the performance of human resources, gets more attention for most owners 
of the organization, because their role can give a very significant effect on the achievement of organizational goals. The existence of performance management practices can minimize the occurrence of conflicts within the body of the organization. This is because there is an effective communication among people in the organization and the establishment of cooperation, both individual and team as well as the similarity in the organizational goals. It has an effect on employee attitudes that further improve their performance, which will ultimately improve organizational performance.

The phenomenon that occurred at Sultan Agung Islamic Hospital Semarang shows that the resulting performance is still not optimal. This is seen from performance measurement based on Key Performance Indicator (KPI) in 2016, which resulted that employee performance targets are still at minimum target threshold. Managerial performance of at least $80 \%$, still achieved $79 \%$, Islamic performance of at least $90 \%$, achieved $89 \%$ and program performance or special performance of at least $76 \%$, achieved $78 \%$ slightly above the minimum target. The efforts to improve performance now focus on performance management practices that consist of setting specific organizational objectives, delegating clear authority, and formulating performance measurement and evaluation.

\section{LITERATURE REVIEW \\ Performance Management}

Performance management has been largely defined by researchers, among others is Armstrong's opinion (2004) who stated that "Performance Management is an integrated concept to achieve sustainable success for organizations by using employee performance improvement methods and by improving individual and group capabilities". Similardefinition is also conveyed by Ma'arif and Kartika (2012) defining that performance management as a continuous communication process which is implemented based on partnerships between employees and their immediate supervisors. Numerous studies have been conducted on the importance of performance management, among others, according to Wibowo (2010), i.e. (1) that there is conformity between organizational objectives and individuals and teams (2) performance improvement (3) motivation for employees (4) commitment improvement (5) core values support (6) improvement of $\mathrm{R} \& \mathrm{D}$ activities (7) competence improvement (8) continuous improvement (9) career planning (10) preventing turn over of employees (11) supporting to total quality and customer service oriented and (12) supporting cultures and cultural adjustment programs.

Basically, the practice of performance management is the implementation / practice implemented from the planned activities. Performance management practices should be recognized as a system that is interconnected among units in an effort to achieve organizational goals. Hood's (1995) opinion stated that “today's public sector organizations have implemented performance management practices as the focus of performance improvement efforts".

According to Sahoo and Jena (2012), it is stated that "The success of employees in achieving organizational goals and mission, can be ascertained because of the success of Performance Management system". Every employee understands what the company wants for the performance goals of each of its employees. Several studies related to performance 
management practices such as those conducted by Econ, Karina and Rooyen (2007) showed that there is a positive correlation between practice or the implementation of Performance management with employee performance results. Another study conducted by Mositadi Tertha Letsoalo (2007) found that performance management has a positive effect on employee attitudes. Based on the results of the above research, it can be formulated hypothesis as follow: $\mathrm{H} 1$ : The higher practice of performance management, the higher employee performance

\section{Employee Work Attitude}

According to Robbins and Judge (2011) attitudes are "evaluative statutes of either favorable or unfavorable about objects, people, or events." The importance of attitudes in organizations, as they can influence behavior. Similar definition is also presented by Pushpakumari (2008) who argued "One of the important things for management is that the behavior of employees in the organization is determined by their attitude". Robbins and Judge (2011) added that attitude has 3 (three) components namely; Cognitive (beliefs of attitude), Affective (feelings of attitude), Behavior (intention to behave). While the indicators of attitude according to Sax (2000), consist of direction, intensity, breadth, consistency and spontaneity. Some of the research that has been done about employee attitudes toward performance is what has been done by Fletcher and Williams (1996) who showed that employee attitude (job satisfaction and commitment) contributes significantly and positively to company performance. Another study from Milliman, et al (2003) found that the application of workplace spirituality and alignment of values significantly affects employee work attitudes. Similarly, the results of research by Letsoalo (2007) resulted that performance management has a positive effect on employee attitudes. Based on the above research, the proposed hypothesis is as follow: $\mathrm{H} 2$ : The higher performance management practice, the higher employee work attitude H3 : The better employee work attitude, the higher employee performance

\section{Islamic Values}

Many experts have defined the term Value, according to Darajat (1984), value is a belief in a pattern of thought, feeling, attachment or behavior that is indicated by a certain identity. Another definition given by Bagus (2002) that value is the quality of a thing that makes it preferable, desirable, useful, or can be an object of interest. A similar understanding is conveyed by Mulyana (2004) that values are references and beliefs in making choices. Research conducted by Parboteeah et. al., (2009) proved that an individual's performance and understanding of religious values are influenced by the powerful impact caused by religious beliefs. Parboteeach et. al., (2009) and Susandari (2011) proved that one's belief will determine an understanding of religious values which in turn will affect his attitude in carrying out his daily activities in whatever environment he or she is in, both in the work environment and the social environment.

This is in line with the opinion of Antonio (2012), that exists in the Qur'an in which becomes the foundation of values for the individual in their work: (1) Rizq for every of His servant who is willing to work (QS. Hud: 6), (2) God's command to always strive for His servant (QS al-jumu'ah: 10), (3) Optimizing oneself to achieve maximum results (QS. An- 
Najm: 39), (4) motivation in making effort, optimistic, and persistent (Surah Ali-Imran: 139, QS Fus-Shilat: 30, QS Yunus: 62), (5) Tawakal in every endeavor (QS. Ali-Imran: 173-174, QS. Fathir : 2, and QS At-Thalaq: 3).

From the above description, where Islamic Values are expected to affect employee behavior, which then affect the direction of achieving organizational goals, therefore it can be arranged hypotheses as follow:

H4 : Islamic values are expected to moderate the correlation of work attitude and employee performance

Based on the above theoretical frameworks, it can be further described in a empirical model of research as follow:

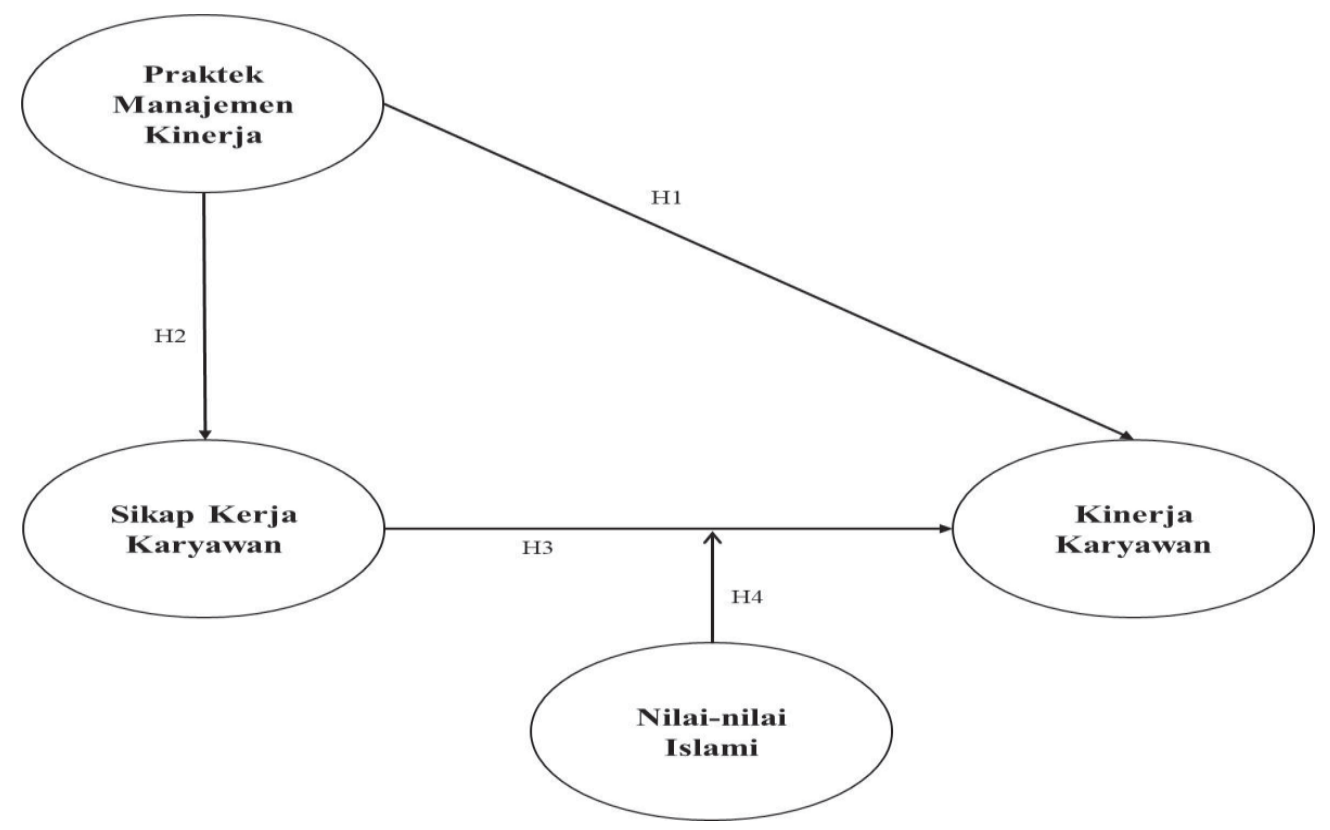

figure 1. Empirical Model of Research

\section{RESEARCH METHOD}

This research included explanatory research. The data collection techniques used in this study was using a questionnaire. The questionnaire was closed, where the answer has been predetermined and the respondent is not allowed to give another answer and then the questionnaire is measured using 5 (five) likert scales. The sampling technique used in this research was purposive sampling so that 100 respondents of permanent employees who work at Sultan Agung Islamic Hospital Semarang, occupying structural and functional position in all work units.

\section{FINDINgS}

\section{Validity Test}

Validity test was conducted to measure the validity or if a questionnaire is valid or not. Validity test with SmartPLS 3 program was done by using convergent size and discriminant validity. 
Convergent validity of the measurement model with reflective indicator was valued by the correlation between item score / component score estimated with SmartPLS Software 3. Discriminant validity of measurement model with reflective indicator was assessed based on the measurement of outer loadings with construct. The results of outer loadings of data processing using SmartPLS 3 are:

Table 1. Outer loadings

\begin{tabular}{llll}
\hline & Employee Performance & Performance Management Practice & Work Attitude \\
\hline KK1 & 0,602123 & & \\
KK2 & 0,783579 & & \\
KK3 & 0,718228 & & \\
KK4 & 0,718228 & 0,718992 & \\
PMK1 & & 0,785578 & \\
PMK2 & 0,628112 & 0,616196 \\
PMK3 & 0,696262 & 0,549543 \\
PMK4 & & 0,505182 \\
SKK1 & & & 0,628689 \\
SKK2 & & & \\
SKK3 & & & \\
SKK4 & & & \\
\hline
\end{tabular}

Source: Processed Primary Data, 2017

From Table 1, it can be seen that the correlation of the construct of performance management practices, work attitude, and employee performance with each indicator is higher than 0.5 , so the constructs in the estimated model meet the criteria of discriminant validity.

\section{Reliability Test}

The reliability test was performed by looking at the composite reability value of the indicator block measuring the construct. The result of composite reliability would result satisfactory value if it is above 0.7 . Here is the composite reability value of the SmartPLS 3 output:

Table 2. Composite Reliability

\begin{tabular}{ll}
\hline & Composite Reliability \\
\hline Employee Performance & 0,799951 \\
Performance Management Practice & 0,801131 \\
Work Attitude & 0,664677 \\
\hline
\end{tabular}

Source: Processed Primary Data, 2017

Table 2 showed that the composite realibility value for all constructs is above 0.7 indicating that all constructs in the estimated model meet the reliable criteria so that they can be used in the next research process. 


\section{Structural Model Testing (Inner Model)}

Inner model describes the relationship between latent variables based on the acquisition of output results from the model of loading factor construction structure which is presented in the form of graph relationships among performance management variables, work attitude, and employee performance. It can be seen in Figure 2 below:

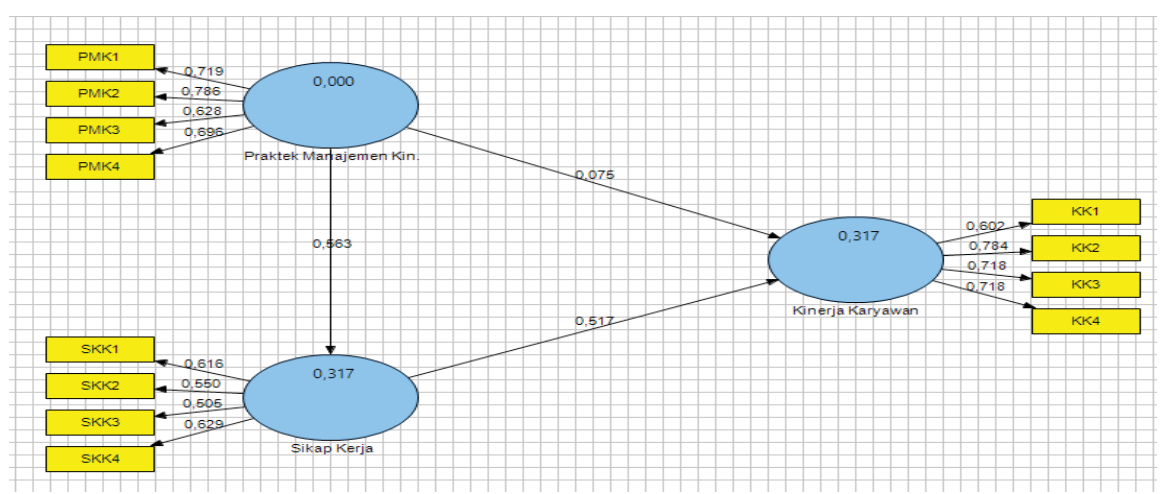

figure 2. Structural Model before Moderation

Table 3. $R$-square

\begin{tabular}{lc} 
& R Square \\
\hline Performance Management Practice & \\
Work Attitude & 0,316606 \\
Employee Performance & 0,316830 \\
\hline
\end{tabular}

Source: Processed Primary Data, 2017

Table 3 showed the value of R-square construct of employee work attitude of 0.3166 which means that the practice of performance management is able to explain variance of employee work attitude of $31.66 \%$ and the rest $(68.34 \%)$ is influenced by other factors which were not examined in this study. Furthermore, the value of R-square is also found in the employee performance construct i.e. 0.3168 which means that the performance management and work attitude is able to explain employee performance variance of $31.68 \%$ and the rest $(68.32 \%)$ is influenced by other factors not examined in this research.

While to determine whether a hypothesis is approved or not, it was then conducted by comparing between $t_{\text {statistic }}$ and $t_{\text {table }}$ with condition if $t_{\text {statistic }}>t_{\text {table }}$, then the hypothesis is approved. For more detail, see Table 4 below:

Table 4. Path Coefficients before Moderation

\begin{tabular}{lccccc}
\hline & $\begin{array}{l}\text { Original } \\
\text { Sample }\end{array}$ & $\begin{array}{l}\text { Sample } \\
\text { Mean }\end{array}$ & $\begin{array}{l}\text { Standard } \\
\text { Deviation }\end{array}$ & $\begin{array}{l}\text { Standard } \\
\text { Error }\end{array}$ & $\begin{array}{l}\text { T } \\
\text { Statistics }\end{array}$ \\
\hline $\begin{array}{l}\text { Performance Management Practice } \rightarrow \\
\text { Employee Performance }\end{array}$ & 0,075110 & 0,080615 & 0,039510 & 0,039510 & 1,901007 \\
$\begin{array}{l}\text { Performance Management Practice } \rightarrow \\
\text { Work Attitude }\end{array}$ & 0,562677 & 0,563095 & 0,029017 & 0,029017 & 19,391186 \\
Work Attitude $\rightarrow$ Employee Performance & 0,517178 & 0,514961 & 0,034921 & 0,034921 & 14,809893 \\
\hline
\end{tabular}

Source: Processed Primary Data, 2017 


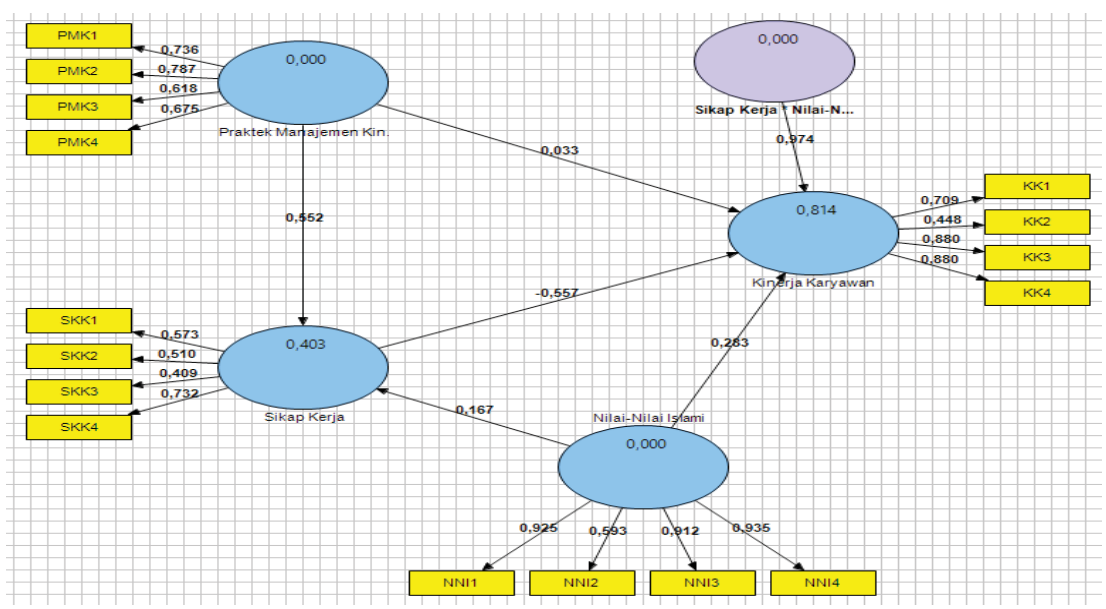

figure 3. Structural Model after Moderation

The result of the path of coefficients after the moderation analysis is presented in Table 5 below:

Table 5. Path Coefficients after Moderated by Islamic Values

\begin{tabular}{llllll}
\hline & $\begin{array}{l}\text { Original } \\
\text { Sample }\end{array}$ & $\begin{array}{l}\text { Sample } \\
\text { Mean }\end{array}$ & $\begin{array}{l}\text { Standard } \\
\text { Deviation }\end{array}$ & \multicolumn{2}{l}{ Standard T } \\
Error & Statistics \\
\hline $\begin{array}{l}\text { Work Attitude * Islamic Values } \rightarrow \\
\text { Employee Performance }\end{array}$ & 0,974429 & 0,948462 & 0,185677 & 0,185677 & 5,247992 \\
\hline
\end{tabular}

Source: Processed Primary Data, 2017 (See appendix 3)

\section{Hypotheses Testing and Discussion}

Based on the test on the correlation among constructs in Tables 4 and 5, the hypotheses proposed in this study can be explained as follows:

\section{a) The Effect of Performance Management Practice on Employee Performance}

The first hypothesis proposed in this study is "The higher performance management practice, the more increased employee performance". Table 4 shows that the correlation between performance management practice and employee performance is positively significant because the value of $t$ statistic is greater than $t$ table ( $t$ statistic 1.90> $t$ table 1.66) at 5\% significance level. Thus, the first hypothesis proposed in this study is: "The higher performance management practice, the more increased employee performance" is accepted.

The results of hypothesis testing proved that performance management practice can have postive significant improvement on employee performance at Sultan Agung Islamic Hospital Semarang. This means that, to encourage employee performance improvement, Sultan Agung Semarang Islamic Hospital needs to facilitate the creation of a neat and timely work completion so as the employees can show their work performance joyfully and happily. The results of this study are in line with the study which was conducted by Kagaari et al. (2010) who proved that performance management practice has a significant positive effect on employee performance. Highly evaluated employees generally exhibit specific behaviors, such as higher attendance, low rates of job change, high employment engagement and increased work-related employment. This will be achieved more optimal if the employees get adequate support and facilities from the organization. 


\section{b) The Effect of Performance Management Practice on Employee Work Attitude}

The second hypothesis proposed in this study is "The higher the performance management practice, the more increased employee work attitude". Based on Table 4 shows that the correlation between performance management practice and employee work attitude is positively significant because the value of $t$ statistic is greater than $t$ table ( $t$ statistic 19.39> $t$ table 1.66) at 5\% significance level. Thus, the second hypothesis which states "The higher performance management practice, the more increased employee work attitude" is approved.

The result of hypothesis testing proved that performance management practice has positive significant effect on work attitude of employees at Sultan Agung Islamic Hospital Semarang. This means that, when performance appraisal is based on organizational vision and mission, and done transparently, the employees would be able to increase their job targets

at Sultan Agung Semarang Islamic Hospital. Employees who work in a well-structured and unstructured organization are very likely to be satisfied with their work. Positive work environments are able to encourage positive attitudes so it can increase their satisfaction with their work (Alvi et al., 2014). Furthermore, employees who have clear goals and sufficient resources to achieve success are more likely to be satisfied with their work. The process of performance management increases possibility that employees will succeed in accomplishing their goals which leads to increased job satisfaction.

\section{c) The Effect of Work Attitude on Employee Performance}

The third hypothesis proposed in this study is "The better employee work attitude, the more increased employee performance". Based on the results of path coefficient analysis in Table 4 , it shows that the correlation between employee work attitude with employee performance is a significant positive effect because the value of $t$ statistic is greater than $t$ table ( $t$ statistic 14.81> t table 1.66) at 5\% significance level. Thus, the third hypothesis in this study which states "The better employee work attitude, the more increased employee performance" is also accepted.

The results of hypothesis testing proved that employee's attitude has positive significant effect on employee performance at Sultan Agung Islamic Hospital Semarang. This means a good work attitude, which is shown by employees, is able to encourage the acceleration of work completion. Previous research has also found that high work attitudes are positively associated with employee performance (Wang et al., 2014). The employees' positive attitudes toward the organization and its values encourage them to engage in business contexts, and work with their peers to improve performance for the benefit of the organization. The approach taken by Harrison et al. (2006) generally focused on the kind of positive attitude of employees that those executives as heads of organizations are able to develop their workforce. The involvement of senior managers is able to link employee work attitudes with higher performance and productivity.

\section{d) The Effect of Islamic Values in Moderating the Corelation of Work Attitude and Employee Performance}

The fourth hypothesis proposed in this study is "Islamic values allegedly moderate the correlation between work attitude and employee performance". Table 5 shows that the interaction variable between work attitude and Islamic values on employee performance is significant because 
$\mathrm{t}$ statistic value is greater than $\mathrm{t}$ table ( $\mathrm{t}$ statistic 5.25> t tabel 1.66) at 5\% significance level. Thus, the fourth hypothesis proposed in this study "Islamic values allegedly moderate the correlation between work attitude and employee performance" is approved. The result of hypothesis testing proved that Islamic values can moderate or strengthen the correlation between work attitude toward employee performance in Sultan Agung Semarang Islamic Hospital.

The importance of religion as a determinant of work values has attracted much attention among scientists. Religion as a source of value is understandable, since three-quarters of the world's population is religious (Zuckerman, 2005). Work values are a guiding principle of human behavior and religion affecting work values in terms of transmitting specific values and norms to its followers, especially in their workplace. Islamic values are not only related to geopolitical issues, but also business and management issues. Managers and employees in cultures which regard Islam as their "moral filter", must recognize the role that Islam plays in shaping the practice and organizational management. Islam places satisfaction in working as a small part of joy because the true satisfaction will be felt by individuals as they reach their goal in the world and in the afterlife. This is confirmed by the statement of Imam Al-Ghazali that a man will achieve the highest satisfaction when he is able to imitate God's attributes such as compassion, love, honesty, justice and others (Sudarsono, 2010). Saleh (2000) found that Islamic values not only affect the work but also the quality of life of the employees. This means that individuals who have a balanced life, whether related to material, non-spiritual or material will feel the highest satisfaction.

\section{CONCIUSION}

This research can generally be concluded that employee performance at Sultan Agung Semarang Islamic Hospital can be strengthened and improved through employee work attitude, performance management practices, and Islamic values. Based on the hypotheses testing proposed by using Structural Equation Modeling (SEM) through SmartPLS 3 software, it can be concluded as follows:

1. Performance management practices can significantly and positively improve performance at Sultan Agung Semarang Islamic Hospital. This means that, to encourage employee performance improvement, Sultan Agung Semarang Islamic Hospital needs to facilitate the creation of a neat and timely work completion so that it will lead to joyful and happiness of employees in showing their performance.

2. Performance management practices have positive significant effect on employee work attitude in Sultan Agung Islamic Hospital Semarang. This means that, when performance appraisal is based on organizational vision and mission, and done transparently, the employees will be able to increase their job targets at Sultan Agung Islamic Hospital Semarang.

3. Employee's attitude can positively and significantly improve employee performance at Sultan Agung Islamic Hospital Semarang. This means that a good work attitude, which is shown by employees, is able to encourage the acceleration of work completion.

4. Islamic values can moderate or strengthen the correlation between work attitudes toward employee performance at Sultan Agung Islamic Hospital Semarang. 


\section{Managerial Implication}

This research has implication on managerial policies as follows:

1. Regarding to the variable of performance management practice, organizations shall ensure the implementation of performance evaluation conducted on a reciprocal basis, either from superiors to subordinates or from subordinates to superiors. This will further enhance communication that is more effective and eliminates mutual suspicion. This twoway communication will provide space for organizers to evaluate each other, as well as to provide justice and transparency. This can be done either by applying performance appraisal system with the $360^{\circ}$ concept.

2. Regarding to the variable of employee's attitude, organizations should encourage spontaneity among employees so that they are able to perform their work effectively and efficiently as needed by the organization. Freedom of expression is one effort that can be taken by management to give confidence to employees, that aspiration and all forms of thought will be heard and appreciated.

3. With respect to the variable of employee performance, organizations should encourage employees to complete work punctually. It aims to maintain and enhance the sensitivity of employees in appreciating the time available by utilizing it proportionally, as well as to achieve the target that has been set. Timely work completion is one of the employees' achievements who deserve to get rewards or serve as one of the indicators of their performance appraisal. Vice versa, there are punishments if there is a mistake or the work completion that is far from the target. But, this needs a deeper study, because to determine the target time of work completion, it must be assessed from various aspects. Leaders should invite subordinates in a discussion to determine the target time achieved.

4. With regard to the variable of Islamic Values, organizations should encourage employees to be optimistic, persistent, and having a disregard (tawakal) unto God so that they have resilience, and not easily discouraged from any failures as well as having an awareness of the importance of relying on God. In order to increase the confidence, it is better that management to create a program that aims to strengthen employees' religion for example by bringing in spiritual motivation, religious studies, or carrying out them in a religious tourism.

\section{limitation of Research}

There are several things to note related to the limitations in this study, including these followings: (1) All construct variables used in this study are measured only on the responses of the same respondents, where such measurement practices have the potential to be bias. (2) The number of samples in this study is too little that only involves 100 respondents so that research results are difficult to generalize. Future research needs to use another, more general, religiosity-related variable, by adjusting the variables and indicators. As for example in the variable of Islamic Values is replaced with the Values of God, the Almighty. Furthermore, the indicator can use more general languages, for example the word "Allah" is replaced with the word "God" for General Hospital or Hospital which is not based on Islam. In addition, it needs to add other variables which are allegedly able to improve employee performance, such as passion for work, job embeddedness, and altruism. 


\section{REFERENCE}

Ajzen, I. and Fishbein, M. (2005), "The influence of attitudes on behavior", in Albarracin, D., Johnson, B.T. and Zanna, M.P. (Eds), The Handbook of Attitudes, Erlbaum, Mahwah, NJ, pp. 173-221.

Alvi, H., Hanif, M., Adil, M., Ahmed, R., and Vveinhardt, J. (2014), "Impact of Organizational Culture on Organizational Commitment and Job Satisfaction" European Journal of Business and Management, Vol. 6 No. 27, pp. 30-39.

Ariyadi, Yuli and Syafruddin, Muchamad (2013) Praktik-praktik manajemen kinerja pada organisasi sector public dan hubungannya dengan kinerja organisasi (studi pada satuan kerja pengelola dana APBN di Indonesia).

Armstrong, M. (2000), Performance Management: Key Strategies and Practical Guidances, Kogan Page, London.

Amstrong, Michael dan Baron (2004), Performance Management, Alih Bahasa: Toni Setiawan. Tugu Publisher. Yogyakarta.

Armstrong, M. and Baron, A. (2007), Performance Management: A Strategic and Integrated Approach to Achieve Success, Jaico Publishing House, Mumbai.

Chen, Z.X. and Aryee, S. (2007), "Delegation and employee work outcomes: an examination of the cultural context of mediating processes in China", Academy of Management Journal, Vol. 50 No. 1, pp. 226-238.

Den Hartog, D., Boselie, P. and Paauwe, J. (2004), "Performance management: a model and research agenda”, Applied Psychology: An International Review, Vol. 53 No. 4, pp. 556-69.

Frank H.M. Verbeeten, 2008, Performance management practice in public sector organzations, impact on performance, Accounting, Auditing and Accountability Journal, Vol. 21 Iss; 3, pp. 427-454.

Fletcher, C. and Williams, R. (1996), "Performance management, job satisfaction and organisational commitment”, British Journal of Management, Vol. 7, pp. 169-79.

Forster, G., Fenwick, J. (2014). The influence of Islamic values on management practice in Morocco. European Management Journal, 1-14.

Ghozali. Imam. 2011. Aplikasi Analisis Multivariate Dengan Program SPSS. Badan Penerbit Universitas Diponegoro. Semarang.

Guest, D. (2011), "Human resource management and performance: still searching for some answers”, Human Resource Management Journal, Vol. 21 No. 1, pp. 3-13.

Harrison, D.A., Newman, D.A. and Roth, P.L. (2006), "How important are job attitudes? Meta-analytic comparisons of integrative behavioural outcomes and time sequences", Academy of Management Journal, Vol. 49, pp. 305-25. 
Ismail, M. Z., and Badron, M. S. (2012). Good governance, adab-oriented tadbir in Islam. Malaysia: IKIM.

Kagaari, J., Munene, J. C., Ntayi, J. M. (2010). Performance management practices, employee attitudes and managed performance. International Journal of Educational Management. Vol. 24 No. 6, pp. 507-530.

Lawler, E., and McDermott, M. (2003). Current performance management practices. World at Work Journal, 12(2), 49-60.

Liu, J., Hui, C., Lee, C. and Chen, Z. (2012), "Fulfilling obligations: why Chinese employees stay?”, International Journal of Human Resource Management, Vol. 23 No. 1, pp. 35 51.

Pollit, C. (2006), "Performance management in practice: a comparative study of executive agencies", Journal of Public Administration Research and Theory, Vol. 16, pp. 25-44.

Prahalad, C. K., and Hamel, G. (1994). Strategy as a field of study: Why search for a new paradigm? Strategic management journal, 15(2), 5-16.

Saleh, Muhammad, 2000, “The Influence of Prayer Tahajud Response to Increasing Resilience Body Immunologic changes,” Dissertation, Surabaya, Airlangga University, 303-310.

Sax (2000), Priciples of educational and Psychological Measurementand Evaluation.

Stalk, G. (1988). Time - the next source of competitive advantage. Harvard Business Review, Jul-Agus, 41-51.

Sudarsono 2010, "Islamic Philosophy” Jakarta: Publisher Rineka Copyright, 21-110.

Verbeeten, F. (2008), "Performance management practices in public sector organisations impact on performance", Accounting, Auditing and Accountability Journal, Vol. 21 No. 3, pp. 427-54.

Wang, H.-J., Lu, C.-Q. and Lu, L. (2014), "Do people with traditional values suffer more from job insecurity? The moderating effects of traditionality", European Journal of Work and Organizational Psychology, Vol. 23 No. 1, pp. 107-117.

Walters, M. (1995), Performance Management Handbook, Institute of Personnel and Development, London.

Zuckerman, P. (2005). In Micheal Martin (Ed.), Atheism: Contemporary rates and patterns in the Cambridge companion to atheism. UK: Cambridge University Press. 